\title{
Movements of Permanent Health Education Triggered by the Training of Facilitators
}

\author{
Cinira Magali Fortuna ${ }^{1}$ \\ Trude Ribeiro da Costa Franceschini² \\ Silvana Martins Mishima $^{3}$ \\ Silvia Matumoto ${ }^{1}$ \\ Maria José Bistafa Pereira ${ }^{4}$
}

This study mapped the movements of Permanent Health Education in the region of Araraquara, São Paulo, Brazil, begun by the Permanent Health Education Facilitators program, promoted by the Ministry of Health and the National School of Public Health. This qualitative study was grounded on the theoretical framework of institutional and schizoanalysis. Data were collected from operative groups of individuals who finished the program. The results were grouped into two plans: micropolitics and organization. Micropolitics indicates the production of different concepts concerning permanent education and different ways to establish it. Autonomy and control and also a tenuous relationship between tutorship and autonomy were highlighted, in the plan of organization. In conclusion, the program was an important device that suffered captures/overcoding but also produced changes in practice.

Descriptors: Education; Health Policy; Human Resources Formation.

\footnotetext{
${ }^{1}$ RN, Ph.D. in Nursing, Professor, Escola de Enfermagem de Ribeirão Preto, Universidade de São Paulo, WHO Collaborating Centre for Nursing Research Development, SP, Brazil. E-mail: Cinira - fortuna@eerp.usp.br ; Silvia - smatumoto@eerp.usp.br.

2 Physician, M.Sc. in Nursing. Secretaria Municipal da Saúde de Ribeirão Preto, SP, Brazil. E-mail: trudefran@yahoo.com.br.

${ }^{3}$ RN, Ph.D. in Nursing, Full Professor, Escola de Enfermagem de Ribeirão Preto, Universidade de São Paulo, WHO Collaborating Centre for Nursing Research Development, SP, Brazil. E-mail: smishima@eerp.usp.br.

${ }^{4}$ RN, Ph.D. in Nursing, Associate Professor, Escola de Enfermagem de Ribeirão Preto, Universidade de São Paulo, WHO Collaborating Centre for Nursing Research Development, SP, Brazil. E-mail: zezebis@eerp.usp.br.
}

\footnotetext{
Corresponding Author:

Cinira Magali Fortuna

Universidade de São Paulo. Escola de Enfermagem de Ribeirão Preto

Departamento de Enfermagem Materno-Infantil e Saúde Pública

Av. dos Bandeirantes, 3900

Vila Monte Alegre

CEP: 14040-902 Ribeirão Preto, SP, Brasi

E-mail: fortuna@eerp.usp.br
} 


\title{
Movimentos da educação permanente em saúde, desencadeados a partir da formação de facilitadores
}

Tem-se, aqui, por objetivo, cartografar os movimentos de educação permanente em saúde, na região de Araraquara, São Paulo, Brasil, disparados a partir do curso de Facilitadores de Educação Permanente em Saúde, do Ministério da Saúde e Escola Nacional de Saúde Pública. É estudo de abordagem qualitativa, sustentado pelo referencial teórico da análise institucional na linha esquizoanalítica, sendo os dados coletados mediante grupos operativos com concluintes do referido curso. Os resultados agrupados em dois planos: micropolítica e organização, apontam, em relação à micropolítica, que houve produção de diferentes conceitos sobre educação permanente e diferentes formas de institucionalização da mesma. No plano da organização, destacam-se a autonomia e o controle e, ainda, a tênue relação entre tutela e autonomia. Conclui-se que o curso foi importante dispositivo que sofreu capturas, mas, também, produziu mudanças nas práticas.

Descritores: Educação; Política de Saúde; Formação de Recursos Humanos.

\section{Movimientos de la educación permanente en salud desencadenados a partir de la formación de facilitadores}

\begin{abstract}
Se tuvo por objetivo cartografiar los movimientos de educación permanente en salud, en la región de Araraquara, Sao Paulo, Brasil, iniciados a partir del curso de Facilitadores de Educación Permanente en Salud, del Ministerio de la Salud y Escuela Nacional de Salud Pública. Es un estudio de abordaje cualitativo, sustentado por el referencial teórico del análisis institucional en la línea esquizoanalítica, siendo los datos recolectados mediante grupos operativos con alumnos terminando el referido curso. Los resultados fueron agrupados en dos planos: micropolítica y organización. Con relación a la micropolítica, apuntan que hubo producción de diferentes conceptos sobre educación permanente y diferentes formas de institucionalización de la misma. En el plano de la organización se destacan la autonomía y el control y también la tenue relación entre tutela y autonomía. Concluimos que el curso fue un importante dispositivo que sufrió capturas, pero también produjo cambios en las prácticas.
\end{abstract}

Descriptores: Educación; Política de Salud; Formación de Recursos Humanos.

\section{Introduction}

This study, based on the theoretical methodological framework of institutional schizoanalysis(1-2), mapped the movements and effects started by a program administered by Permanent Health Education Facilitators (PHE) and promoted by the Ministry of Health (MH) and the Brazilian National School of Public Health in the region of the Regional Health Department in Araraquara (RHD III), SP, Brazil.

The PHE was established by the $\mathrm{MH}^{(3)}$ as a national policy and proposes that through the collective analysis of work processes, individuals can become mutually responsible for encouraging autonomy and delivering care from the perspective of integrality of attention in health ${ }^{(4-5)}$

Based on significant learning, the PHE also proposes that this analysis be developed through dialogue, in round tables addressing the problems and difficulties faced in the routine in which care is developed, in management, in the training of professionals to work in the Brazilian Health System and in social participation and control(4-7). PHE operates in the micropolitics of the work process and, from this perspective, it involves the molar (macro) and molecular (micro) levels not as opponents, but 
as expressions of the routines of policies, economies, desires and ways of living ${ }^{(2,8)}$.

To disseminate and encourage conversation tables within the PHE throughout the country, the $\mathrm{MH}$ triggered several strategies, among them, training PHE facilitators $^{(8)}$. The ministry sought to inspire workers, managers, professors, students and users of the health system to play a role in which they would facilitate and coordinate dialogue and reflection about the work performed in round tables, thereby causing discomfort and at the same time promoting a re-invention of collectives moving toward the principles of the Single Health System (SUS) ${ }^{(4,8)}$. The program to train PHE facilitators introduced a device - the PHE round table $\mathrm{e}^{(4,6,8)}$, which is an arrangement capable of producing a new and innovative way of working in health but which could also be apprehended by the established movements ${ }^{(8)}$.

Therefore, this study maps the lines of a complex network of many inputs and flows that compose the movements and effects produced by such a training program. Schizoanalysis denominates cartographic process $^{(9)}$. This is not an evaluative study, but rather identifies the movements produced: the meanings and non-meanings built by the subjects and not about them.

Permanent Health Education is an important component in the current scenario of health and educational policies $^{(10)}$, hence, the productions ${ }^{(3-8,11)}$ analyzed and reported in Brazil strengthen the implementation of SUS and educational policies in the field of health. This investigation contributes toward this goal.

\section{Method}

\section{Cartography - the path and analysis proposed}

Cartography is the method of schizoanalysis and consists of paying attention to affections and resonances spread over multiple plans and surfaces that compose the landscape ${ }^{(1,9,12)}$, which is reality. The landscape in this study is psychosocial, the movement of multiples, who already are or may become. The cartographer enters into the psychosocial landscape with his/her vibrating body: one who affects and is affected, seeking meanings and that which no longer has meaning. Cartography, cartographer and landscape express themselves by hybridizing, mixing, separating, multiplying. It opens up paths for a history that is woven in encounters/dis-encounters of the production of subjectivities. Written records capture and give substance to what is by nature in motion, hence is temporary and hides many other possible records.

Groups also see and talk; they are dispositifs in action $^{(13)}$. The cartographers and health workers within these groups produced a report; a history woven through affecting and being affected, through speaking and silence, through coming-into-being and being. The weaving of this mapping is done in group meetings according to the theoretical foundation of the operative groups $^{(14)}$, on a path in which research is built from the definitions of groups, subjects and fields.

\section{The operative groups}

The groups are singular compositions in which contrasts, dilemmas and conflicts are expressed, considered by some institutional analysts a field of analysis and intervention ${ }^{(2)}$. Human beings are gregarious by nature, live in groups to satisfy socially and historically constructed needs, which are the motivation to establish contact, bonds and learning(14). The subject emerges from a bonding system, contradictions, from the interplay between needs and satisfaction, subject and context. The operative group is "a set of individuals interconnected through a mutual internal representation and who are explicitly or implicitly committed to perform a task that is their purpose, interacting through complex mechanisms of assumption and adjudication of roles"(14).

The groups have two essential organizers: tasks and bonds. The task is composed both of actions directed toward the achievement of the group's objectives and pre-task, a situation in which the group experiences "difficulties" achieving such objectives. Anxiety and fear of losing, of being attacked, characteristic of the pretask, can immobilize the group and cause temporary deviation from its task. The fear of loss is related to losing individuality, knowledge and power. The movements of the task and pre-task are possible from the bonds that direct the purposes; they enable those involved to be included as actors, subjects of their praxis, so that new forms of subjectification emerge ${ }^{(14)}$.

In this process in which subjectivities are produced, the group and its members produce narratives and events. These individuals compose the group, plan strategies of transformation and give rise to projects. The project and learning become articulated from the perspective of subjects who can grasp reality in a mutually changing relationship.

\section{The setting, the definition of the study's participants and data collection}

The PHE experiences were mapped and the key informants (tutors in the training program administered to PHE facilitators and the involved professionals) in the 
different regions of the country were identified in order to define the study's setting. Settings were chosen in different states: two of them were in the state of São Paulo, one in the city's metropolitan area and one in the interior of the state, in Araraquara. This region is located in the Northeast macro region in the state of São Paulo and comprises 26 cities and a population of 929,068 inhabitants in 2007.

RHD III integrates the São Paulo northeast PHE center and had 20 slots in the $1^{\text {st }}$ training program to $\mathrm{PHE}$ facilitators; $65 \%$ completed the program. The project was presented in a meeting held with the potential participants in which the objectives and possibility of making a collective analysis of the process they had experienced were discussed, then individuals consented to participate in the study.

After establishing the region to be studied, the definitions concerning the study such as its participants, setting and duration, number of meetings and experiences to be analyzed, followed the assumptions of Health Education ${ }^{(3-4)}$, giving priority to collective consensus and decisions. These aspects are also coherent with the theoretical-methodological contribution of operative groups $^{(14)}$, especially in relation to the centrality of the task and the establishment of bonds as the groups' main organizers.

Ten individuals participated in the study: six PHE facilitators (one dentist, three nurses and two speech therapists), one tutor (dentist), and three individuals working in the PHE in RHD III (one social worker and two psychologists). These three individuals were invited and their names were suggested by the facilitators themselves and by the tutor because these individuals' performance stood out in PHE actions in their region and because they had studied the program's didactic material, though they were not officially enrolled in the program.

The number of meetings, dates, schedule and participants were defined by the group itself in the first meeting. At this point, the experiences that would be analyzed were also spontaneously defined; the participants suggested those experiences they deemed important. Five operative groups with meetings of two hours each were held between April and May 2008. An average of nine participants attended each meeting. The absences were due to work reasons.

The ethical principles guiding this study complied with resolution 196/96: subjects' anonymity, exchange of interpretations and hypotheses concerning the discussions and the group process with the study's participants. They were also assured of care in dealing with divergences and impasses experienced by the group. Data collection was initiated after the Ethics Research Committee at the University of São Paulo at Ribeirão Preto, College of Nursing approved the project (protocol 0748/2007). All the participants signed free and informed consent forms.

In the first meeting, after negotiating the group contract, the experiences of the PHE based on the facilitators' training program were discussed. The remaining meetings were initiated by reading a report of the previous meeting and the group was guided by the task of collectively analyzing the experiences previously agreed upon.

The report was a narrative of the group ${ }^{(14)}$ and highlighted the main issues addressed, the group's resistance and changing movements, what emerged, and questioned the group about possible interpretations. Its content originated mainly from the records performed by a silent observer (one of the members of the coordination team of the operative groups). Testimonies, gestures, facial expressions and silent pauses were recorded and, after the sessions, the coordinator and the observer would meet and develop the meeting's report. From a research point of view, this report had a critical sense and permitted re-validating the empirical material being produced during the investigation.

The group's coordination was guided by the Pichonian $^{(14)}$ theoretical framework and schizoanalysis, based on the task of producing collective analyses of the experiences of PHE facilitators and the production of subjectivities $^{(1-2,9,12)}$.

The group meetings were recorded in digital media and then transcribed. The empirical material was composed of transcriptions, narratives of the meetings, and a field diary used by the researchers.

\section{Results and Discussion}

Two concomitant and immanent plans of analyses were identified during the exploration and construction of the field research: the plan of PHE micropolitics as an act being produced and the organizational plan in which autonomy and control were highlighted in confrontation with the management. These plans were identified in the empirical material and grouped according to constitution of areas of tension in the organizations ${ }^{(8)}$, defined in reference to institutional analysis. 


\section{Plan of PHE micropolitics as an act in production}

In this plan, the groups' movements were expressed as well as what derived from their affections produced during the meetings of the facilitators and tutoring with cartographers. One initial element of analysis was configured as a doubt: Who would be included in the group as a study's subject? This question emerged and was expressed by one facilitator concerning the desire of a professor from a local university to participate in the study. The group decided not to include this individual in the group and rationally made it explicit. However, the discussion concerning who could or could not perform PHE remained implicit, that is, only those who became able after attending the program: the PHE experts? The discussion triggered a paradox between knowledge and non-knowledge, expressed in the report of one of the facilitators; she expressed, as spokeswoman, her fear of participating in it and of exposing herself: I don't know whether I should participate or whether I can make any contribution, because I don't have much experience to share [...] (Group 1).

Hence, a contradiction was evidenced in the PHE facilitator's role. On one side, this individual has the task of mediating collective processes of analyses, a place of transition, which does not have ready recipes and answers, which aims to encourage the autonomy of the other workers, users and managers. On the other side, the expert is the one who defines what should be done and how something must be done ${ }^{(12)}$, a way established and predominant in educational processes. Nonetheless, one hardly rips apart from this established place of knowledge and power that encourages dependency, which could be questioned by the program's experience.

The participants' testimonies concerning their experiences in coordinating the round tables revealed their desire to have an identity: PHE facilitator. Having an identity is vainglorious: it requires a name, acknowledgment, a post, the difference that distinguishes but also excludes. In the subsequent meetings, the role of the PHE facilitator was re-considered given the possibility of capture of this dispositif by its institutionalization.

The PHE was presented in this group in many forms and many questions were asked: Does attending the PHE program mean - or not mean - taking previously structured programs?; Does attending the PHE program mean participating in meetings with practitioners from one specific activity or multiprofessional?; Does attending the PHE program mean promoting events or is it the opposite?
From a conceptual point of view, the PHE program is not just about events and previously structured programs directed to specific professions ${ }^{(4)}$. These definitions should have been re-signified by attending the program, but they were included in the group discussions and were largely debated and re-constructed through the dialectic task/ pre-task.

These are definitions that approximate the PHE theoretical perspective that the group built: it is a network of round tables (collective) - encouraging people to discuss; it is learning with the simple things and with another individuals, which requires people to detach from preconceived ideas; it is to make team meetings; it is to assume democratic positions, giving voice to those who are rarely listened to and who are rarely allowed to talk; it means making agreements, a pedagogy of making pacts; PHE is a process of promoting growth; it is a way to take care of the team. These are some examples: [...] the problematization, and what is significant [...] I guess $I$ can get it from this negotiation, which is PHE pedagogy" [...] (Group 3).

The group dynamics allowed that these conceptions concerning PHE and the facilitator were expressed and re-viewed. The discussions that emerged in the group movement during the pre-task, which reveals the group's difficulty or tensions, were polarized: it was either one thing or another. Exchange and learning was observed in the task with the inclusion of one idea and another and another ${ }^{(12,14)}$.

As to the program's results, the group analysis identified the dissemination of the $\mathrm{PHE}$, the appropriation of concepts, a multiplicity of them, and it also encouraged round tables in health services, an aspect that will be explored in the organizational plans.

Facilitators and tutor could re-visit the PHE practices in the group meetings and visualize the differences among them. They also faced the various conditions necessary to execute the tasks of the facilitators' program and the PHE round tables. The participants manifested tensions in the production of acts in the PHE when they reported that some were exclusively designated for PHE work, for example, the tutor of the program, while for others it represented extra work, something they had to perform in addition to their regular responsibilities.

The PHE program tutors joined the pedagogical process when students were present and also when activities were performed in distance education with official ones. They facilitated the learning process. 
The tutor in the region of Araraquara dedicated himself full time to this responsibility, which was an exception, an uncommon situation in Brazil and may have influenced the movements identified in the group.

Despite operational differences, some acknowledged the PHE as another way to work. [...] You have to put effort into it, have to read, to study, I guess that a lot of people don't allow themselves to do it, thinking 'I won't manage it, it's a lot of work, I have a lot of activities to do in the city', because we work for the city, care delivery and PE. (Group 4).

The group did not directly discussed the evaluation of the results of their acts within the PHE, but this perspective was implicit in the group and in the fact that some were chosen to occupy functions in the RHD related to the PHE and other were not. One former facilitator participating in this group was appointed coordinator of the Training and Development Center that integrates the humanization policy and the PHE. Another facilitator was chosen to work at the permanent educational center and was waiting for the official designation during the data collection period.

This relief in the micropolitical plan of PHE production shows it is immanent in relation to the plan of organization and politics. The way this aspect was manifested in the group stands out by being implicit: the experiences of both facilitators were not considered in the analysis at that time of the group meetings even though it was initially agreed to do so.

When they recalled their experiences in the round tables, the workers' resistance, they could talk about their own resistance, they experienced them again in that moment and constructed new meanings. [...] resistance I guess [...] because when the process begins, people don't believe in it much, then after a while, you see that things start to be built, it generates something [...] I guess that it brings out the issue of conflicts like hierarchy of power, organization, the tendency is that an organization becomes vertical (controlling all levels) and when you propose these round tables, you try to make the organization/decision-making more horizontal. (occupying the same level) (Group 3).

They stressed that resistance has many facets: participating to create opposition; the manager's support when one has no idea of what PHE means, and explicit conflicts. The managers disavowed the collective with authoritarian decisions, and even worse, they undermined the possibility of change. Again, the micropolitical plans of the production of PHE acts, of the organization and politics indicated interfaces that do not separate from each other.

Dealing with groups and collectives enabled individuals to learn about the management of round tables, another effect of the program: the round tables require one to learn while in action. [...] you go to the group with certain knowledge but we have a different experience there, you work with the group's need. (Group 4).

The participants consider that, in the beginning, the round tables were marked by complaints and difficulties, and people talked a lot about things that did not work out. Such attitudes might be related to their resistance to change. The fear of being attacked for not knowing, for not having ready answers, of losing the place one had achieved - that of PHE facilitator - the fear of loosing the co-workers' admiration led the group to take a defensive posture(15).

Usually, this defensive behavior leads the participants to put out the anguish that accrues from group processes, and the managers, those in charge, become responsible for what does not work, as we will see in the plan of organizations. Individuals had to learn to exercise an active waiting so people in less acknowledged positions and with less prestige would express their ideas and desires. Participants without a bachelor's degree do not express themselves: it takes time. They can contribute a lot; the coordinator has to manage to enable these people to express themselves (Group 3). The teams' habitual hierarchy, in which those with a bachelor's degree talk first based on the technical and social work division(16-17), does not make sense anymore and other arrangements where everyone can speak up are created.

The anxious expectation placed on the coordinator is another aspect of the group ${ }^{(14)}$ process present in the PHE round tables. Dealing with this depositing, while not being omnipotent to respond to the group's demands but thinking jointly with the group and facilitating dialogues, requires learning from experience. These individuals tell how they experienced this difficulty, which triggered "a desire to be able to manage it": You provoke some things, give explanations, raise problems, but it's difficult when you have to conclude, to link everything, to found something concrete [...] (Group 3)

When the coordinator takes on the responsibility for the process him/herself, for the rights and wrongs, s/he is reproducing the institutions' established functioning mode: only some know where to go, what does not allow for the new, the collective construction, the creation ${ }^{(12)}$. Hence, the responsibility for the process becomes very heavy. But it was a very heavy burden; it was a great, very great responsibility (Group 1)

Co-responsibility - which is one of the objectives of the PHE - needed to be re-considered by this collective 
at that point: [...] I don't know if it was my fault for having agreed, for having brought something [...] we tried to do it in this entire process, but... there was a point when I missed clarity, an objective [...] I had the "responsibility" (scare quotes added by the speaker herself) to facilitate and guide those people, and you end up as a reference, you have to take these people from one place and to another, and sometimes I got lost in this process (Group 2).

Seriousness was expressed in their faces, one of the participants exposed his/her lack of knowledge and was sincerely welcomed by the others, because his/her testimony reflected their own and affected them all.

This plan of analysis shows that other tools could help PHE facilitators to manage the round tables, but the training program did not offer such tools and these needed to be sought/created. Dealing with the structureunstructured dynamic would be a tool, understanding that clarity and certainty can co-exist with doubts and uncertainty: a constant interplay. Pause and movement are possible and necessary.

The participants named the following indicators for the PHE that was working: listening, "light" returned, participation of physicians in the round tables and work agents, who usually do not express themselves much during discussions, were allowed to talk. The outcomes of the round tables were considered positive and irreversible changes, something nobody takes from them. There is also another contradiction in relation to the PHE, which refers to a desire that the "good" remains, to be stable. A desire to leave positive marks while being a facilitator and produce irreversible changes that hamper and deny the health work process, the PHE. The idea of a "right" way/place led them to paths of illusion and control. The plan reveals a difficulty in dealing with uncertainty. At the end of a meeting they told a cartoon: [...] my son watches Sponge Bob [...] he goes to a party, he gets there with an already determined role and says, 'from 9 to 10 I talk to Patrick, from 10 to 11 I stay'... then this person arrives, and he says 'oops, I have to talk from 9 to 10 with this guy'... then somehow he's outside the party and says 'ah!!' And then this spontaneous thing happens and he gets desperate, 'Oh, I'm loosing control, so what now?' Then the party ends, people go out and say 'ah, this was the best party I've ever been to in my whole life'... [laughs] [...] I guess we are like this cartoon, we want to be in control and sometimes do not simply let it happen. (Group 4).

Spontaneity seen as the good path and awareness that they cannot totally control situations, were significations that resulted from that collective and were congruent with the PHE assumptions. Another aspect that was already mentioned and that was learned is the possibility of change and freedom in the process of these discussions, though there were moments in which people and situations were refereed to as if these did not change: didn't I tell you? It doesn't change. (Group 1)

Change was associated with listening, bonds and conversations: the first PHE movement we managed to construct, was to establish bonds among people [...] talk, learn to talk to one another, learn to look at, learn to listen [...] And there were some effects, there were some professionals who changed their practice, we managed to determine that there was a change in practices, change in listening, reception [...] and we call people to the round table you know, users who had a certain influence in the community [...] one of them even participated on the city's board of health [...] she started to participate, another lady also. (Group 3).

Knowing one better, talking, looking at, are attitudes that affect the health workers' practice. The PHE round tables can be a place/way where/in these caregivers can be cared for. The participants also felt cared for by the cartographers through their attentive listening and the way they heeded their spoken and unspoken words.

In the penultimate meeting, this group found that the PHE facilitators training program should have offered more time to individuals to appropriate concepts and provided more opportunities to discuss what was not well understood: I guess it is essential, because it was necessary to continue a formally organized group, [...] a board that would meet frequently to discuss these issues for a certain period of time [...] (Group 3).

In a movement of tasking and intense exchange, the group constructs important reflections: in PHE processes, you cannot count on a ready recipe and this can be distressing, but you need to bear not knowing, the process... to bear this - this waiting time... (Group 4), which bears the unedited, the new unspeakable, the time that keeps the power of coming into being. There are in it possibilities of producing singular subjectivities, other modes of expression(2). They report they are not the same after experiencing the process: I guess that the PHE process, it's a process that causes discomfort [...] you discuss more difficulties, so I guess that it makes you grow, it is this discomfort that make us transform, we got that, so I think that this is also the great beauty of the process, we are getting used to having a certain conduct, a behavior, a way of doing things, where we are not used to deal with frustrations, disagreements, distress. (Group 2).

In the micropolitical plan, the space of operative groups enables the exploration of PHE production while an act, a live work $^{(18)}$. From this process emerged different concepts, actions, and conditions for the 
facilitator's exercise, among others. The manifestation of these differences oscillated between exclusion and the separation of subjects and affections, and inclusion and support.

The participants experienced looking at themselves from the perspective of another and looking at the others, enabling the production of a "middle ground" that promotes significant learning $(7,11,15)$.

\section{Plan of organization: autonomy and control in conflict with the management}

Different actors operate in this plan depending on their ability to govern and their inclusion in the management process ${ }^{(18)}$. Cartography enabled us to identify how strained this dispute was on a daily basis, among standards and established rules, autonomy and control. The facilitators named a series of difficulties faced in the performance of PHE activities since operational difficulties in the performance of activities with workers during the work journey and also how the round tables and collective decisions were disavowed. We are stopped at the operational level, at the functioning of the health unit itself [...] The issue of sending a document to close the unit from $3 \mathrm{pm}$ to $5 \mathrm{pm}$ is a complicating factor; you can't work PHE from $12 \mathrm{pm}$ to $2 \mathrm{pm}$, while they are working [...] I don't get it, he assembles a team, puts you there and trains people, and puts another two people and don't give you political support? What for...! (Group 1)

The apprehension of established movements ${ }^{(12)}$ triggered by the PHE were characterized by the exclusion of the groups' facilitators. They were removed from the round table management, which led to breach of agreements. The expression of one of the meetings was deliver the sold merchandise (Group 2). In the role of sellers of "a merchandise", the facilitators agreed on democratization of work, but they could not "deliver it" because it was the management's responsibility.

To exemplify, there was an agreement with workers in one city that there would not be unfair dismissal and that new workers would not be hired based on the mayor's suggestion but through criteria and selection. However, one individual was hired through political means. It caused uneasiness, smothered hopes, created a lack of motivation in the participants involved in the PHE round tables and resulted in an emptying movement, confirming the idea that it doesn't help, there's no solution (Group 2). Hence, the facilitators who were 'putting themselves at risk" felt disavowed and as if they had restricted governance in this change process.

The main actors with established power to capture of the PHE, acknowledged as those who "impeded the flow of the process" were: managers, administrators, and nurses. [...] now, we're talking about frustration, my big frustration [...] is that my nurse colleagues, for me they're a deception [...] it's the most resistant group, the most difficult, the most lazy and I particularly have trouble working with this professional and I look at new girls, who graduated four, five years ago, they're like plastered... with extremely bad, negative postures, antihumanization, anti-reception...disappointing, there you go, I said it. Laugh. (Group 1).

The PHE round tables in some health services remained as effective in the collective: the movement there continued without us [...] one of the nurses became enthusiastic and maintained the round tables, and from what I know, there're still round tables there. (Group 2)

Another effect was the institutionalization of training programs directed to workers. These programs were already defined with different conceptions of PHE in the micropolitical plan. The denomination of the programs are often changed, training for permanent education, but the work processes through agreements and reviews are not effectively changed.

The idea of "assault" on management emerged in the discussion, assault on power/knowledge, threatening individuals in leadership positions: In the first day after the workshop, it was calm, but the day after... she noticed there was a phone call in which they were talking about her (facilitator) and took the initiative to ask that the communication be directed to her. The mayor's assistant and another colleague asked her what had I done? What did I think I was doing? And harshly clarified that the one who does politics here is the mayor. But she didn't falter, she rather proposed that they review their concepts about politics... said that I was only improving management authorized by you, or by whoever was there. (narrative of Group 5).

Other aspects related to the tension between autonomy and tutorship ${ }^{(18)}$ publicized by the development of PHE actions were the working conditions and the way workers deal with the problems they face, involving issues of their personal lives: [...] I started acknowledging what the reality I'd work with was [...] a consummate alcoholic, a person who had an unresolved emotional, sentimental situation [...] ah! And coincidence or not, at this time, I worked with a social worker who'd found out her husband had a child with another woman, so the emotional state of this unit [...] that was the reality I had to work with. (Group 3).

While discussing this experience, the group considered the subtle line between tutorship and care, and the difficulties found in the facilitator's role, capable of caring without encouraging dependency and not losing the focus from the care delivered to the health 
service's users.

Yet in the organizational plan, we need to contextualize the historical dispute of power in the state departments with the local levels through their technicians and RHD, so we can resume the discussion concerning the tension presented in the micropolitical plan when we mention the appointment of some facilitators to positions in the RHD. When power was decentralized to the cities, these regional spaces somewhat lost their function and their technical ascension over the city managers. The format the PHE politics assumed with Decree 1996/2006(5), indicated there are other roles and powers for these state regional instances.

Workers from the city and state headquarters and also from health units participated in the group discussions and this tension implicitly permeated the collective analysis of experiences and the group process itself, though the group did not find any interference in the group's functioning due to this dispute.

\section{Final Considerations - PHE in permanent construction}

We presented two immanent and interdependent plans of analyses. Contradictions were identified between the PHE proposal and the facilitators' experience, among which we highlight: the difficulty democratizing work spaces; the construction of co-responsibility, the difficulty in advancing known educational practices of production of pre-determined programs for specific professions; the desire to remain, to control processes, to occupy positions, among others.

We highlight in the micropolitical plan the materialization of concepts of Permanent Health Education, the differences between experiences and expectations. As a result of the program, we stress the dissemination and the different forms of the PHE institutionalization: the traditional programs directed to health workers with new names and also the achievement of space for the occurrence of team meetings. The PHE proved to be a dispositif capable of generating discomfort in order to unravel one of the main forms of apprehension and contradiction: the reproduction of programs and team meetings within the logic of those who know and those who do not know and the expectation of individuals to be acknowledged as the program's expert.

In the organizational plan, tension between autonomy and control, and autonomy and tutorship is highlighted. The movements triggered by the PHE somewhat lost their effect given the disavowal of the groups by the managers themselves, the exclusion of facilitators and the few tools they had to develop strategies to negotiate disputes of projects. It came out that the managers did not have the dimension of the potentiality of PHE and its implication.

The rich process of putting oneself in analysis was triggered by the program and by the practice of the PHE facilitators, which were re-discussed in the study's groups. It also produced good meetings that might have created new meanings for the educational and health practices. However, this perspective may be easily captured by the established ways of educating, caring, managing and researching.

\section{References}

1. Marc Roberts RMN. Capitalism, psychiatry, and schizophrenia: a critical introdution to Deleuze and Guattari's Anti-Oedipus. Nursing Philosophy. 2007;8:114-27.

2. Baremblitt G. Introdução à esquizoanálise. Belo Horizonte: Biblioteca do Instituto Félix Guattari; 1998. $123 \mathrm{p}$

3. Ministério da Saúde (BR). Portaria n. 198/GM/MS de 13 de fevereiro de 2004 (BR). Institui a Política Nacional de Educação Permanente em Saúde como estratégia do Sistema Único de Saúde para a formação e o desenvolvimento de trabalhadores para o setor e dá outras providências. 2004 [acesso 01 out 2009]. Disponível em: http://www.saude.pb.gov.br/site/geab/ portaria198.pdf.

4. Ceccim RB, Feuerwerker LCM. O quadrilátero da formação para a área da saúde: ensino, gestão, atenção e controle social. PHYSIS Rev Saúde Coletiva. 2004; 14:41-65.

5. Ministério da Saúde (BR). Portaria GM/MS n.1.996, de 20 de agosto de 2007. Dispõe sobre as diretrizes para a implementação da Política Nacional de Educação Permanente em Saúde e dá outras providências. 2007 [acesso 01 out 2009]. Disponível em: http://www. saude.pb.gov.br/site/geab/portaria2007.pdf

6. Murofuse NT, Rizzotto MLF, Muzzolon ABF, Nicola AL. Diagnóstico da situação dos trabalhadores em saúde e o processo de formação no polo regional de educação permanente em saúde. Rev. Latino-Am. Enfermagem. 2009;17(3):314-20.

7. Carotta F, Kawamura D, Salazar J. Educação permanente em saúde: uma estratégia de gestão para pensar, refletir e construir práticas educativas e processos de trabalhos. Saúde Soc. 2009; 18(supl.1):8-51. 
8. Merhy EE, Feuerwerker LCM, Ceccin RB. Educación Permanente em Salud: uma estratégia para intervenir em la micropolitica Del trabajo em salud. Salud Colectiva. Maio-agosto $2006 ; 2(2): 147-60$.

9. Rolnik S. Cartografia sentimental: transformações contemporâneas do desejo. São Paulo: Estação Liberdade; 1989. 304 p.

10. Davini MC. Paradigmas y prácticas de evaluación em programas educativos para El personal de salud. In: Roschke MA. Evaluación em procesos de educación permanente y capacitación em salud: experiências y lecciones. Washington, D.C: OPS; 2006. p.3-20.

11. Pereira EG, Soares CB, Campos CMS. Uma proposta de construção da base operacional do processo de trabalho educativo em saúde coletiva. Rev. Latino-Am. Enfermagem. 2007,15(6):1072-9.

12. Baremblitt G. Compêndio de Análise Institucional e outras correntes: Teoria e prática. 2. ed. Rio de Janeiro: Editora Rosa dos Tempos; 1994. 204 p.

13. Barros RDB. Dispositivo em ação: o grupo. In: Silva $A E$, et al., organizadores. Subjetividade. Questões contemporâneas. São Paulo (SP): Hucitec; 1997. p. 183-91.

14. Pichon-Rivière E. O processo grupal. 3 ed. São Paulo (SP): Martins Fontes; 1982. 181 p.

15. Zimerman DE, Wainberg AK, Barros CASM, Baptista F Neto, Mazieres G, Viçosa GR, et al. Como trabalhamos com grupos. Porto Alegre (RS): Artes Médicas; 1997. p. 424.

16. Rocha SMM, Almeida MCP. O processo de trabalho da enfermagem em saúde coletiva e a interdisciplinaridade. Rev. Latino-Am. Enfermagem. 2000;8(6):96-101.

17. Fortuna CM, Mishima SM, Matumoto S, Pereira MJB . O trabalho de equipe no programa de saúde da família: reflexões a partir de conceitos do processo grupal e de grupos operativos. Rev. Latino-Am. Enfermagem abril 2005;13(2):262-8.

18. Merhy EE. Saúde: A cartografia do trabalho vivo. São Paulo: Hucitec; 2002. 189p. 